\title{
Temperature-dependent Expression of Flagella of Listeria monocytogenes Studied by Electron Microscopy, SDS-PAGE and Western Blotting
}

\author{
By M. PEEL, W. DONACHIE* AND A. SHAW \\ Moredun Research Institute, 408 Gilmerton Road, Edinburgh EH17 7JH, UK
}

(Received 27 November 1987; revised 7 March 1988)

\begin{abstract}
Washed cells of Listeria monocytogenes serotype $4 \mathrm{~b}$, grown in broth culture at $20^{\circ} \mathrm{C}$ and at $37^{\circ} \mathrm{C}$, were examined by electron microscopy for the presence of flagella. Many flagella were seen in cells grown at $20^{\circ} \mathrm{C}$, whereas at $37^{\circ} \mathrm{C}$ very few were expressed. Flagella sheared from the cell surface were partially purified by differential centrifugation. Using SDS-PAGE and Western blotting two distinct protein bands were seen in this preparation, both with an apparent molecular mass of approximately $29 \mathrm{kDa}$. Further purification of these proteins was achieved by gel filtration and ion-exchange chromatography. Whole organisms grown at $20^{\circ} \mathrm{C}$ and $37^{\circ} \mathrm{C}$ were examined in Western blots using an affinity-purified polyclonal antibody, and a monoclonal antibody, both directed against $29 \mathrm{kDa}$ putative flagellin. Bacteria grown at $20^{\circ} \mathrm{C}$ expressed abundant flagellin, whereas only trace amounts could be detected in organisms grown at $37^{\circ} \mathrm{C}$. It is concluded that organisms grown at $20^{\circ} \mathrm{C}$ both produce and assemble flagellin at the cell surface, and that flagellin production is a less marked feature of organisms grown at $37^{\circ} \mathrm{C}$.
\end{abstract}

\section{INTRODUCTION}

Listeria monocytogenes has a characteristic temperature-dependent motility, so that while it will grow within a wide temperature range $\left(4-42^{\circ} \mathrm{C}\right.$ ), it is motile only between 20 and $25^{\circ} \mathrm{C}$ (Wilson \& Miles, 1964). This motility is attributable to the possession of peritrichous flagella, which can be demonstrated histochemically (Leifson \& Palen, 1955), and which are employed as antigens in serological classification (Paterson, 1940). Despite subsequent revision (DonkerVoet, 1966; Seeliger \& Hohne, 1979) the classification first proposed by Paterson essentially remains unchanged. Thus $L$. monocytogenes is serotyped according to possession of certain somatic ' $\mathrm{O}$ ' antigens together with flagellar ' $\mathrm{H}$ ' antigens as demonstrated by agglutination tests with homologous and heterologous absorbed antisera. Since Paterson (1940) defined four flagellar antigens by these techniques, little further of the structure or the biochemistry of $L$. monocytogenes flagella has been reported.

Studies of flagella from other bacterial species have revealed a consistent basic structure of linear arrays of protein subunits (flagellin) together with small quantities $(1-5 \%, w / w)$ of carbohydrate and lipid (Nossal \& Ada, 1971). Rose (1976) described individual molecules of flagellin as being either globular or ovoid subunits which are closely packed helically about the long axis of the flagellum. The molecular masses and arrangements of the flagellin subunits vary between species.

For analysis, bacterial flagella can be detached readily from the cell body by mechanical shearing, and harvested by cycles of differential centrifugation. Flagella from Pseudomonas spp. and Vibrio cholerae have been prepared in this way (Whiteside \& Rhodes-Roberts, 1985; Richardson \& Parker, 1985).

Abbreviations: HRP, horse-radish peroxidase; SPF, specific pathogen-free. 
This paper reports (i) the appearance of $L$. monocytogenes flagella as seen by electron microscopy; (ii) the preparation of $L$. monocytogenes flagellin and the determination of its molecular mass by SDS-PAGE; (iii) the preparation of purified flagellin, which enabled the production of antibodies for the study of flagellin expression at room temperature $\left(20^{\circ} \mathrm{C}\right)$ and at body temperature $\left(37^{\circ} \mathrm{C}\right)$.

\section{METHODS}

Bacteria. L. monocytogenes serotypes $4 \mathrm{a}$ and $4 \mathrm{~b}$ were isolated on $7 \%(\mathrm{v} / \mathrm{v})$ sheep blood agar plates in pure culture from the brains of sheep with listerial encephalitis. Cultures were maintained by lyophilization in skimmed milk. Bacteria were grown in 1 litre volumes of trypticase soy broth to the early stationary phase of growth $\left(12 \mathrm{~h}\right.$ at $37^{\circ} \mathrm{C}$; $24 \mathrm{~h}$ at $20^{\circ} \mathrm{C}$ ). Numbers of live bacteria as colony-forming units (c.f.u.) were estimated by serial dilution on blood agar according to the method of Miles $e$ al. (1938).

Electron microscopy. A drop of bacterial suspension, fixed in $0.5 \%$ glutaraldehyde, was placed on carbon/Pioloform-coated grids. After 20-30 s the excess was removed and the grids were allowed to air dry. They were then washed with distilled water. Shadowing was carried out in an Edwards 306 coating unit using gold/palladium metal. The shadow angle was $20^{\circ}$. For negative staining, grids were stained with $0.5 \%$ ammonium molybdate. Grids were examined in a Siemens Elmiskop A electron microscope.

Preparation of crude flagella. Bacteria grown at $20^{\circ} \mathrm{C}$ were harvested by centrifugation at $5000 \mathrm{~g}$, washed twice in phosphate/saline buffer (PBS: $0.01 \mathrm{M}$-sodium phosphate, $0.15 \mathrm{M}$-sodium chloride; $\mathrm{pH}$ 7.6) and resuspended at a ratio of $5 \mathrm{ml}$ PBS per litre of broth culture. Samples $(10 \mathrm{ml})$ of this bacterial suspension were added to stoppered glass universal bottles together with 12 glass beads $(2 \mathrm{~mm}$ diameter). The bottles were clamped vertically on a microid wrist-action flask shaker (Griffin \& George) and shaken vigorously for $30 \mathrm{~min}$ at $20^{\circ} \mathrm{C}$. The bacterial suspension was centrifuged at $5000 \mathrm{~g}$ and the supernatant retained. The bacterial pellet was washed twice with PBS by vigorous pipetting to remove sheared flagella trapped within the cell mass. The supernatant and cell washings were pooled and centrifuged at $14000 \mathrm{~g}$ for $40 \mathrm{~min}$ to clear remaining bacteria, and the resulting supernatant centrifuged at $200000 \mathrm{~g}$ for $90 \mathrm{~min}$ to harvest crude flagella. A sample of the pellet was taken for electron microscopy.

Purification of flagellar proteins. The crude flagellar pellet was solubilized by boiling for $3 \mathrm{~min}$ in PBS containing $1 \%(\mathrm{w} / \mathrm{v})$ SDS and $2 \%(\mathrm{v} / \mathrm{v}) 2$-mercaptoethanol. SDS and 2-mercaptoethanol were removed by dialysis against PBS with $0.02 \%$ sodium azide for $18 \mathrm{~h}$ at $20^{\circ} \mathrm{C}$. The resulting dialysate was concentrated by centrifugation through the membrane of a microconcentrator (Centricon-10, Amicon). The solution was applied to a Superose 12 gel filtration column (FPLC, Pharmacia), and eluted with $0.02 \mathrm{M}$-Tris and $1 \mathrm{M}-\mathrm{NaCl}$ at $\mathrm{pH} 7.4$. Maximum loading was $200 \mu \mathrm{l}$ of solution containing approximately $2 \mathrm{mg}$ protein, which was eluted at a flow rate of $0.2 \mathrm{ml} \mathrm{min}{ }^{-1}$. The major peaks were collected and analysed by SDS-PAGE. The peak containing flagellin was dialysed for $18 \mathrm{~h}$ at $4{ }^{\circ} \mathrm{C}$ against $0.1 \mathrm{M}$-Tris $\mathrm{pH} 7.4$; samples $(0.5 \mathrm{mg}$ ) were applied to a Mono $\mathrm{Q}$ ion-exchange column (FPLC, Pharmacia) and eluted with a $0 \cdot 1-0.4 \mathrm{M}-\mathrm{NaCl}$ gradient at a flow rate of $2.0 \mathrm{ml} \mathrm{min}^{-1}$. The resulting peaks were again checked using SDS-PAGE.

SDS-PAGE. A discontinuous system employing slab gels $0.75 \mathrm{~mm}$ thick with a $12 \%(\mathrm{w} / \mathrm{v})$ separating gel and a $4 \%$ stacking gel, and the buffer system of Laemmli (1970), was used. Samples were diluted $1: 1$ with sample buffer containing $2 \%(\mathrm{w} / \mathrm{v})$ SDS and $4 \%(\mathrm{v} / \mathrm{v}) 2$-mercaptoethanol and boiled for $3 \mathrm{~min}$ before application to the gel. Geis were stained either with $0.5 \%$ Coomassie Blue, or by the silver stain of Morrissey (1981). The molecular mass of flagellin was calculated by reference to standard markers.

Western blotting. The technique of transfer to nitrocellulose was that of Burnette (1981) as modified by Herring \& Sharp (1984). Blots were blanked using a 1:1 dilution of horse serum in washing buffer. For detection, sheep, rabbit and mouse antibodies were used, followed by the appropriate peroxidase-conjugated probes. Donkey antisheep IgG and donkey anti-rabbit IgG horse-radish peroxidase (HRP) conjugates were obtained from the Scottish Antibody Production Unit and West of Scotland Blood Transfusion Service. Affinity-purified sheep anti-mouse conjugate was obtained from Mr A. Dawson at the Moredun Research Institute. All conjugates were used at a $1 / 400$ dilution in washing buffer containing $5 \%(v / v)$ horse serum.

Antiserum. Antiserum was raised in a conventional sheep by repeated subcutaneous (s.c.) inoculation of formaldehyde-killed $L$. monocytogenes serotype $4 \mathrm{a}$, grown in broth at $37^{\circ} \mathrm{C}$, in complete Freund's adjuvant, and in a specific pathogen-free (SPF) lamb by s.c. inoculation of formaldehyde-killed $L$. monocytogenes serotype $4 \mathrm{~b}$, grown in broth at $37^{\circ} \mathrm{C}$, in incomplete Freund's adjuvant.

Anti-flagellar serum was produced in a rabbit by inoculation of flagellin purified by column chromatography. A total of $380 \mu \mathrm{g}$ of flagellin was given intramuscularly in three separate inoculations, the initial inoculation in complete Freund's adjuvant, and the subsequent two in incomplete Freund's adjuvant.

Preparation of affinity-purified anti-flagellar antiserum. The $29 \mathrm{kDa}$ flagellar protein (1 mg obtained by gel filtration and ion-exchange chromatography) was coupled to $3 \mathrm{ml}$ of swollen activated CH-Sepharose 4B (Pharmacia) by the method recommended by Pharmacia, and packed in a $10 \times 1 \mathrm{~cm}^{2}$ column. Following 
equilibration with a neutral running buffer $(0.1 \mathrm{M}$-sodium phosphate with $0.5 \mathrm{M}-\mathrm{NaCl}), 2 \mathrm{ml}$ volumes of rabbit antiserum were applied to this column. Bound antibody was eluted from the column with $0 \cdot 1 \mathrm{M}-\mathrm{glycine} / \mathrm{HCl}$ pH 2.3, neutralized, and stored at $4{ }^{\circ} \mathrm{C}$.

Preparation of monoclonal antibody. Adult female Balb/c mice were given $25 \mu \mathrm{g}$ crude flagella in divided doses by foot-pad inoculation (Miller et al., 1975). The initial inoculation was given with complete Freund's adjuvant and $2 \%(v / v)$ Tween 20. Subsequent inoculations were given with incomplete Freund's adjuvant. A final inoculation was given in PBS.

Single-cell suspensions of popliteal lymph node cells were fused with equal numbers of NS-O myeloma cells according to the method of Galfre et al. (1977) as modified by Reading (1982). Cells were cloned three times by limiting dilution and inoculated into the peritoneal cavities of Pristane-primed mice.

The isotype of the monoclonal antibody used in this study was determined by ELISA to be IgG2. This ELISA employed purified flagellin as the coating antigen and HRP-conjugated isotype specific anti-mouse reagents raised in rabbits as the probes (Miles Scientific).

Protein assay. Protein estimations were done using commercial assay reagents (BCA-Protein Assay, Pierce Chemical Company). Protein concentration was determined by reference to a standard curve calculated for bovine serum albumin (Sigma).

\section{RESULTS AND DISCUSSION}

Temperature-dependent appearance of flagella of $L$. monocytogenes serotype $4 b$ as seen by transmission electron microscopy

Bacteria grown at $20^{\circ} \mathrm{C}$ had many flagella distributed in a peritrichous manner with many points of attachment. Fig. $1(a)$ shows three such bacteria which exhibit the typical number of flagella and their apparently random arrangement around the cell. By contrast, examination of organisms grown at $37^{\circ} \mathrm{C}$ revealed no fully formed flagella, although a few flagellar fragments were occasionally seen both attached to cells and distributed throughout the cell mass (Fig. $1 b$ ).

\section{Relationship of flagella to $29 \mathrm{kDa}$ protein}

The clear gelatinous precipitate obtained by ultracentrifugation of flagella sheared from the cell surface was seen to be an almost homogeneous flagellar mass (Fig. 2). Approximately $2 \mathrm{mg}$ of crude flagellar protein per litre of broth culture was recovered. By SDS-PAGE and silver staining the crude flagellar material was shown to be composed largely of a $29 \mathrm{kDa}$ protein (Fig. $3 a$, lane 1). This was confirmed by Western blotting using antiserum raised against whole formol-killed organisms (Fig. 3b, lane 1).

\section{Purification of $29 k$ Da proteins}

When crude flagellar protein was depolymerized and applied to a Superose 12 molecular sizing column, an elution profile of three distinct peaks was obtained (Fig. 4). The first, large peak (A) was present consistently and always appeared immediately following the void volume of the column. As no protein could be detected in this peak either by colorimetric protein assay or by silver staining of gels it was considered to be an artefact due to residual SDS in the sample. Silver-staining of SDS-PAGE preparations of peaks B and C showed that peak B contained only minor protein bands, whereas peak $\mathrm{C}$ contained $29 \mathrm{kDa}$ flagellar protein. Silver staining and Western blotting of peak $C$ are shown in Fig. 3(a) (lane 2) and Fig. 3(b) (lane 2) respectively. Peak B material was discarded, and peak $C$ was applied to a Mono $Q$ ion-exchange column in a further attempt to remove contaminating proteins.

Three further peaks were obtained from the Mono Q column (Fig. 5). Peaks 1, 2 and 3 were eluted with $0 \cdot 16,0 \cdot 31$ and $1.0 \mathrm{M}-\mathrm{NaCl}$ respectively. When examined by SDS-PAGE and silverstaining each of the three peaks was found to contain the $29 \mathrm{kDa}$ flagellar protein (Fig. $3 a$, lanes 3, 4 and 5). In addition, peak 1 contained two bands of molecular mass less than $29 \mathrm{kDa}$, and peak 3 contained small amounts of a $43 \mathrm{kDa}$ contaminating protein. When the same protein profiles were examined by Western blotting, the $29 \mathrm{kDa}$ flagellar proteins are again seen to be the most prominent feature of each peak (Fig. 3b, lanes 3, 4 and 5).

The major proteins of all three peaks eluted from the ion-exchange column were in each instance of molecular mass $29 \mathrm{kDa}$. A likely explanation of this phenomenon is that the peaks represent flagellin at different stages of polymerization. Abram \& Koffler (1964) showed that 

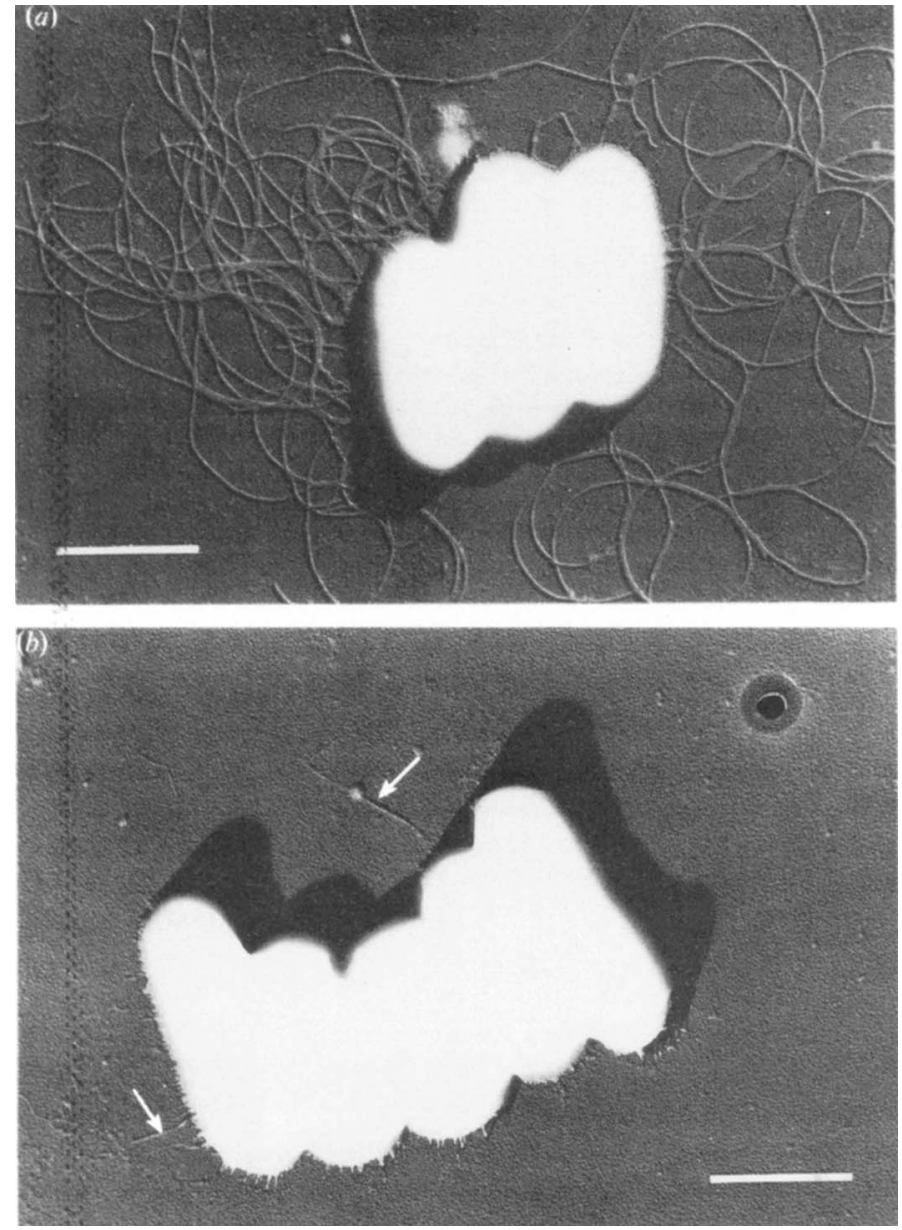

Fig. 1. Transmission electron micrographs of cells of $L$. monocytogenes grown at $20^{\circ} \mathrm{C}(a)$ and $37^{\circ} \mathrm{C}(b)$, shadowed with gold/palladium metal. (a) Note the abundance of flagella; (b) arrows denote fragments of flagella only. Bars, $0.75 \mu \mathrm{m}$.

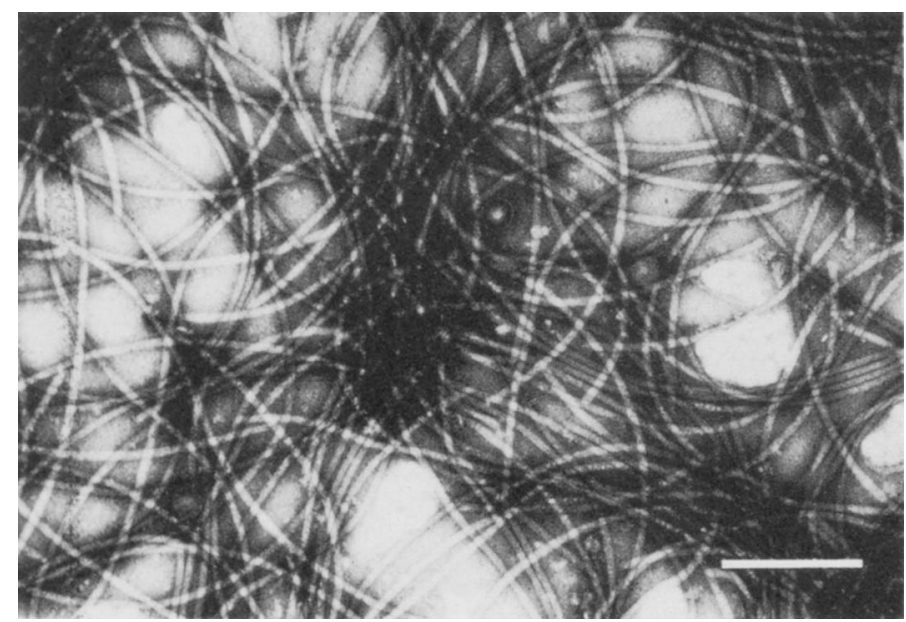

Fig. 2. Transmission electron micrograph of a negatively-stained ultracentrifuged pellet of flagella of L. monocytogenes. Bar, $0.25 \mu \mathrm{m}$. 


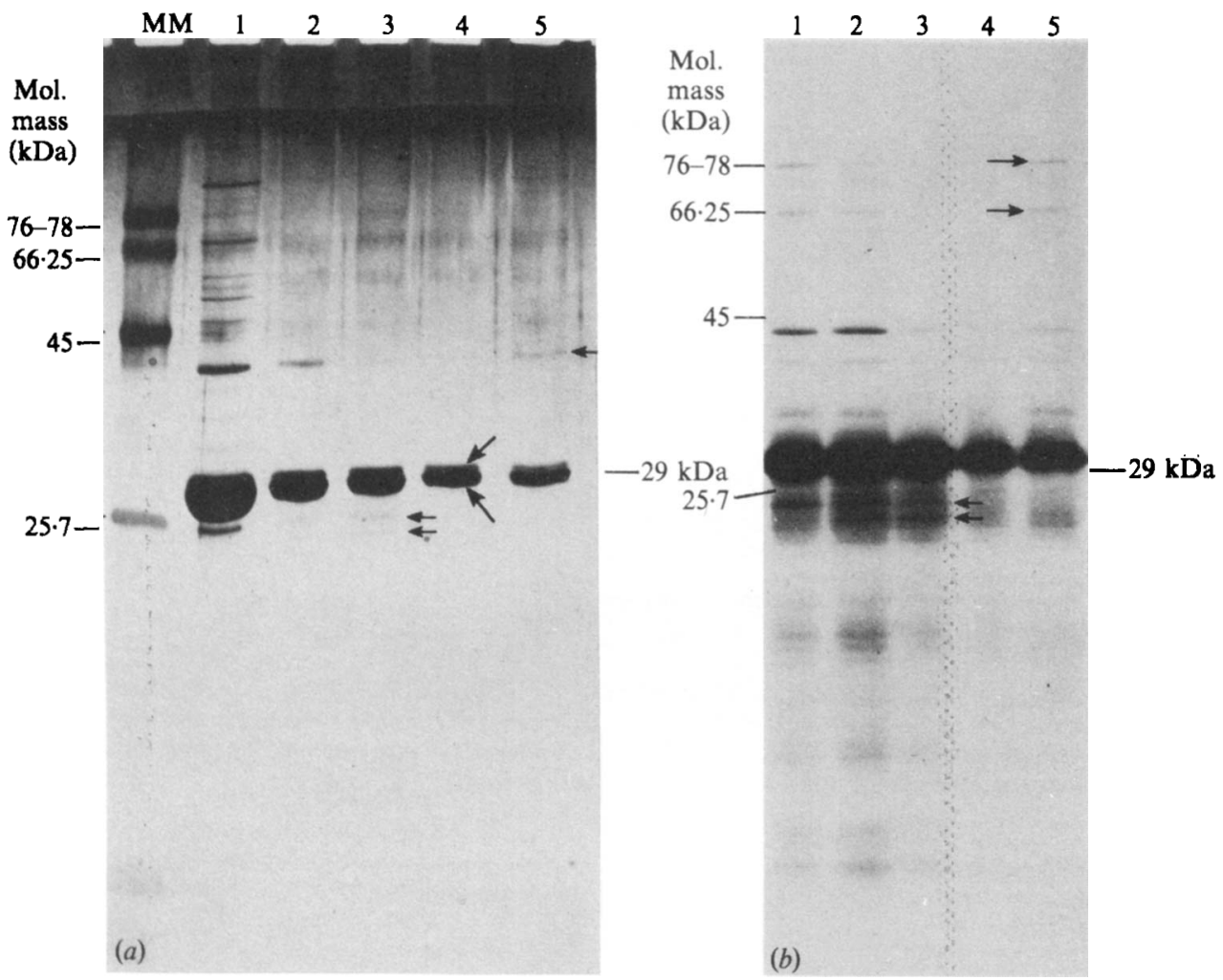

Fig. 3. SDS-PAGE of (1) crude flagellar extract $(2 \mu \mathrm{g})$, (2) peak $C$ from Superose $12(1 \mu \mathrm{g})$, (3) peak 1 from Mono Q $(1 \mu \mathrm{g})$, (4) peak 2 from Mono $Q(1 \mu \mathrm{g})$, (5) peak 3 from Mono $Q(1 \mu \mathrm{g})$, followed by: (a) silver staining of the gel (small arrows show contaminating bands; large arrows denote the flagellin proteins); (b) immunoblot analysis using conventional sheep hyperimmune serum raised against $L$. monocytogenes serotype $4 \mathrm{a}$ (arrows show contaminating bands). MM, molecular mass markers.

Bacillus flagellin polymẹrized into flagellar filaments at low ionic strengths. It is reasonable to suppose that $18 \mathrm{~h}$ of dialysis of the sample against $0 \cdot 1 \mathrm{M}$-Tris before application to the ionexchange column allowed some polymerization of the flagellin monomer to occur. This could account for differences in net positive charge and subsequent differences in elution from the column.

It is evident from silver-staining and Western blotting that peak 2 contained $29 \mathrm{kDa}$ listeria flagellin in a highly purified state. Material from peak 2 was therefore used for the preparation of affinity-purified mono-specific antiflagellar serum.

Listeria flagellin comprised at least two proteins of nearly identical molecular mass (see Fig. $3 a$, lane 4). This finding is compatible with the observation of Schmitt et al. (1974), who identified two flagellin components of almost the same molecular mass in SDS-PAGE gels of Pseudomonas rhodos. It is not clear whether both proteins are present on a single flagellar structure or whether they represent two types of flagella, each composed of a single protein species.

\section{Expression of $29 \mathrm{kDa}$ protein by L. monocytogenes $4 \mathrm{~b}$ at $20^{\circ} \mathrm{C}$ and $37^{\circ} \mathrm{C}$}

In a comparative study of $L$. monocytogenes grown at $20^{\circ} \mathrm{C}$ and at $37^{\circ} \mathrm{C}$, using SDS-PAGE and staining with Coomassie Blue, some major differences were apparent (Fig. 6). Flagellin was the predominant protein elaborated by organisms grown at $20^{\circ} \mathrm{C}$, whereas it was not an apparent feature of organisms grown at $37^{\circ} \mathrm{C}$. Moreover, with the exception of a distinct protein band of $43.7 \mathrm{kDa}$ and two bands of higher molecular mass (72.4 and $75.9 \mathrm{kDa})$, L. monocytogenes 


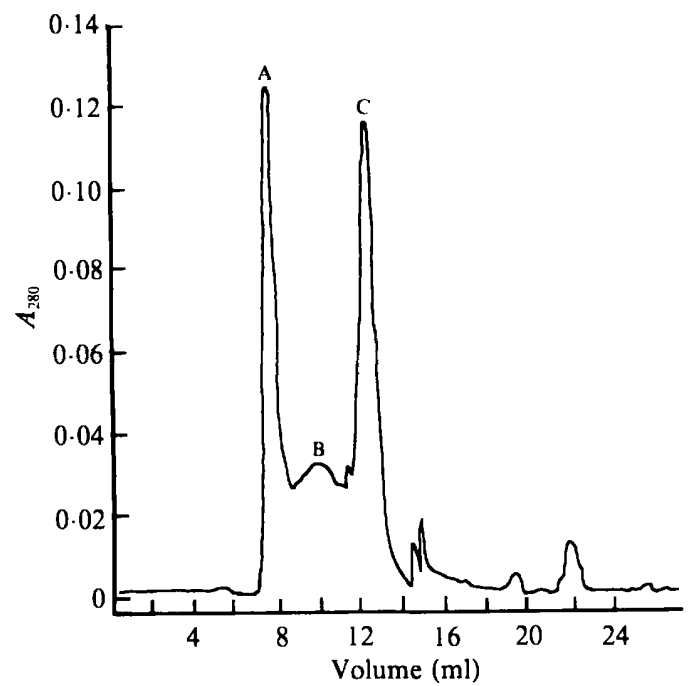

Fig. 4

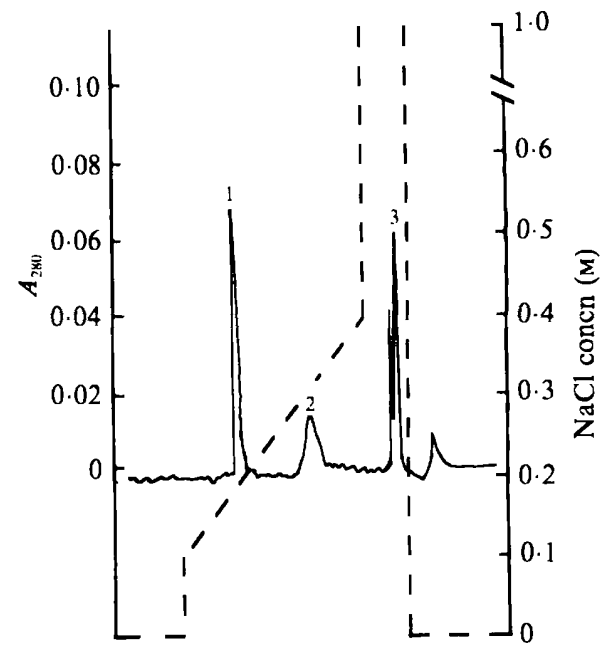

Fig. 5

Fig. 4. Purification of flagellin by gel filtration using Superose 12. Samples of $2 \mathrm{mg}$ were applied and the flow rate was $0.2 \mathrm{ml} \mathrm{min}-1$. Flagellin was present in peak $C$. Fractions from this peak $(14-16 \mathrm{ml})$ were applied to the Mono-Q ion-exchange column (see Fig. 5).

Fig. 5. Anion-exchange chromatography (Mono-Q) of peak $C$ (see Fig. 4) eluted with a segmented 0-1 $\mathrm{M}-\mathrm{NaCl}$ gradient (---). A $0.5 \mathrm{mg}$ sample was applied and eluted at a flow rate of $2 \mathrm{ml} \mathrm{min}^{-1}$, giving three peaks of absorbance (1, 2 and 3), which were analysed by SDS-PAGE and Western blotting (Fig. 3).

grown at $20^{\circ} \mathrm{C}$ appeared to express lower concentrations of protein than did bacteria grown at $37^{\circ} \mathrm{C}$. These differences were also apparent by Western blotting using antiserum raised in an SPF lamb against $L$. monocytogenes serotype $4 \mathrm{~b}$ grown at $37^{\circ} \mathrm{C}$ (Fig. 7 b). Again, flagellin was the largest single antigenic component of bacteria grown at $20^{\circ} \mathrm{C}$. At least four minor polypeptides were detected in the $29 \mathrm{kDa}$ area of preparations of organisms grown at $37^{\circ} \mathrm{C}$, but since the blot was developed using a polyclonal antiserum raised against whole organisms it is unclear which (if any) of these bands might be referable to flagellin. The protein band at $43.7 \mathrm{kDa}$ was again more prominent in bacteria grown at $20^{\circ} \mathrm{C}$. However, with the above two exceptions, all other protein antigens appeared to be present in smaller amounts in bacteria grown at the lower temperature.

Finally, for more specific detection of flagellin at the two temperatures, affinity-purified antiflagellin rabbit serum and the monoclonal antibody were used to develop Western blots of the two preparations (Figs $7 a$ and $7 c$, respectively). Using the affinity-purified antiserum a substantial difference was evident in the amount of flagellin synthesized by bacteria grown at the two temperatures, with a faint trace of flagellin at $37^{\circ} \mathrm{C}$ only just discernible, consistent with the rudimentary expression of flagella seen by electron microscopy (Fig. $1 b$ ). Conversely, at $20^{\circ} \mathrm{C}$ a very strong $29 \mathrm{kDa}$ band was present. Using the monoclonal antibody, a much narrower $29 \mathrm{kDa}$ band was detected in bacteria grown at $20^{\circ} \mathrm{C}$, and none was seen in bacteria grown at $37^{\circ} \mathrm{C}$.

These results show that there is both synthesis and assembly of flagellin subunits at $20^{\circ} \mathrm{C}$ but that these occur to a considerably reduced extent at $37^{\circ} \mathrm{C}$. However, the very small amount of flagellin expressed at $37^{\circ} \mathrm{C}$ may nevertheless be a significant antigen. This is suggested by the result shown in Fig. 7(b), where the blot has been developed using antiserum from the SPF lamb. This animal was inoculated with washed formaldehyde-killed organisms which had been grown at $37^{\circ} \mathrm{C}$ and prepared with no concern for flagellar preservation. Nevertheless, the lamb has seroconverted markedly to the $29 \mathrm{kDa}$ flagellin, as can be seen in lane 1 . (No anti-flagellar antibody was detected in serum taken from this animal before immunization - data not shown.) 


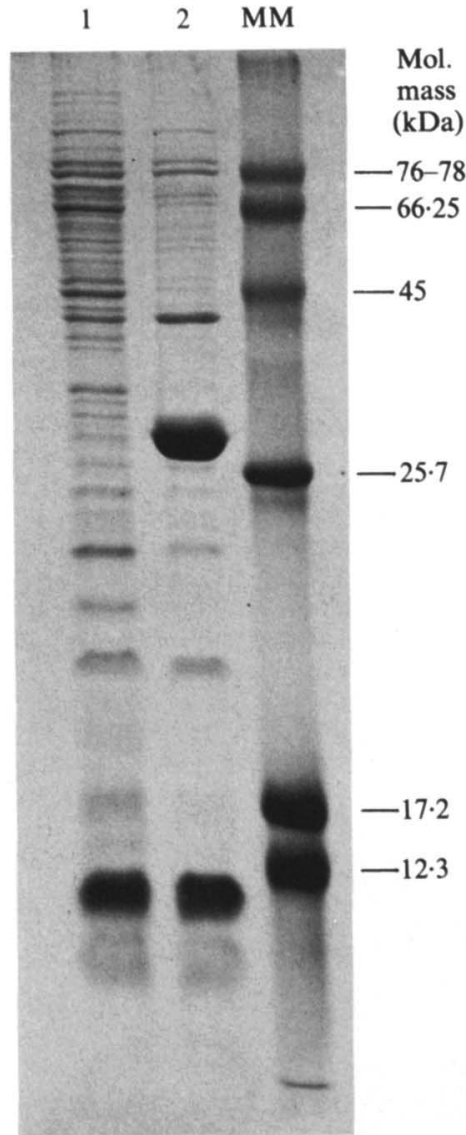

Fig. 6

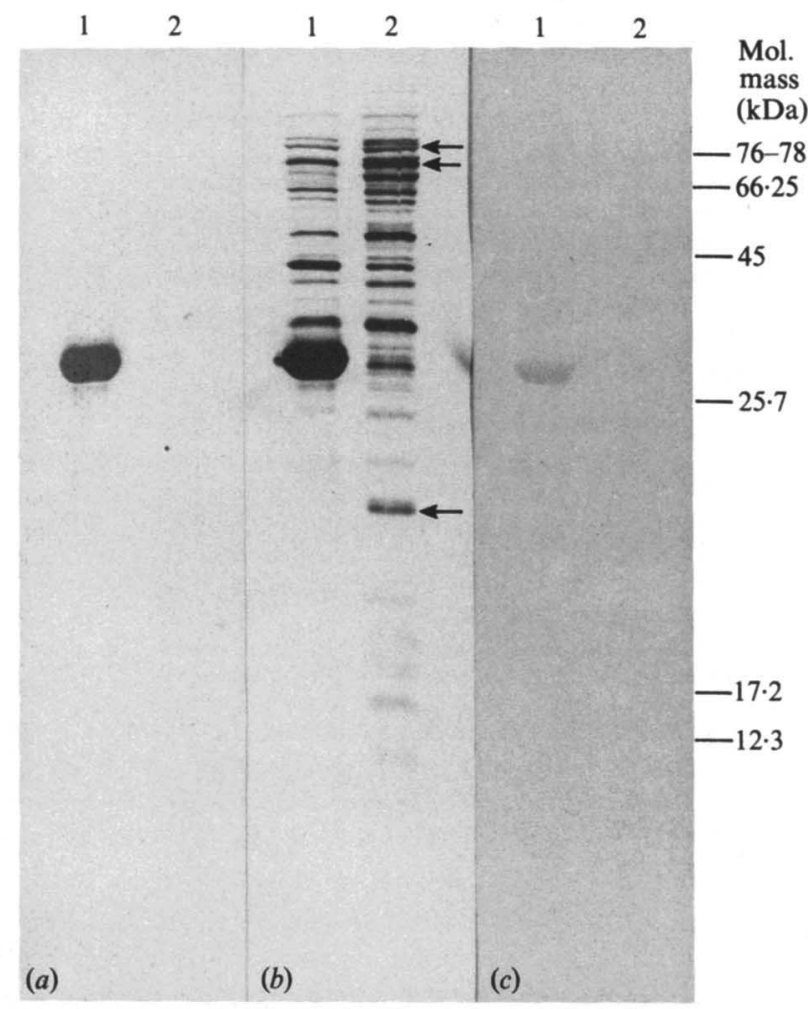

Fig. 7

Fig. O. SUS-rAUE of $4.4 \times 1 U^{\prime}$ c.I.u. or $L$. monocytogenes serotype 40 grown al $(1)$ JI $C$ and $(\angle)<U C$. Bacteria were boiled in solubilizing buffer before application to the gel. The gel has been stained with Coomassie Blue. MM, molecular mass markers.

Fig. 7. Western blot of $2.9 \times 10^{9}$ c.f.u. of $L$. monocytogenes serotype $4 \mathrm{~b}$ grown at (1) $20^{\circ} \mathrm{C}$, and (2) $37^{\circ} \mathrm{C}$, examined using: (a) rabbit affinity-purified anti-flagellar serum; (b) SPF lamb antiserum raised against serotype $4 \mathrm{~b}$ grown at $37^{\circ} \mathrm{C} ;(\mathrm{c})$ monoclonal antibody. The arrows denote some areas of antigenic differences between the two preparations.

Since it seems possible that small quantities of flagellin are highly immunogenic when formolkilled bacteria are inoculated together with adjuvant, it is suggested that the serological response following experimental and natural infection should be investigated. High titres in animals following a live infection would imply that purified $29 \mathrm{kDa}$ flagellin could be used in solid-phase immunoassay for a sensitive serological test.

We thank Mr J. Menzies and Mr A. Dawson for technical assistance. Miss M. Peel was the recipient of an AFRC veterinary postgraduate study award.

\section{REFERENCES}

ABRAM, D. \& KOFFLER, H. (1964). In vitro formation of flagella-like filaments and other structures from flagellin. Journal of Molecular Biology 9, 168185.

BURNETTE, W. N. (1981). 'Western blotting': electrophoretic transfer of proteins from sodium dodecyl sulfate-polyacrylamide gels to unmodified nitrocel- lulose and radiographic detection with antibody and radiodinated protein A. Analytical Biochemistry 112, 195-203.

DONKER-VOET, J. (1966). A serological study on some strains of Listeria monocytogenes. In Proceedings of the 3rd International Symposium on Listeriosis, Bilthoven, The Netherlands, pp. 133-137. 
Galfre, G., Howe, S. C., Milstein, C., Butcher, G. W. \& Howard, J. C. (1977). Antibodies to major histocompatibility antigens produced by hybrid cell lines. Nature, London 266, 550-552.

Herring, A. J. \& Sharp, J. M. (1984). Protein blotting: the basic method and its role in viral diagnosis. In Recent Advances in Virus Diagnosis, pp. 115-125. Edited by M. S. McNulty \& J. B. McFerran. The Hague, Boston \& London: Martinus Nijhoff.

LAEMMLI, U. K. (1970). Cleavage of structural proteins during the assembly of the head of bacteriophage T4. Nature, London 227, 680-685.

LeIFSON, E. \& PALEN, M. I. (1955). Variations and spontaneous mutations in the genus Listeria in respect to flagellation and motility. Journal of Bacteriolagy 70, 233-240.

Miles, A. A., MisRa, S. S. \& IRwiN, J. O. (1938). The estimation of the bactericidal power of the blood. Journal of Hygiene 38, 732-749.

Miller, H. R. P., Ternynck, T. \& Avrameas, S. (1975). Synthesis of antibody and immunoglobulins without detectable antibody function in cells responding to horseradish peroxidase. Journal of Immunology 144, 626-629.

MORRISSEY, J. H. (1981). Silver stain for proteins on polyacrylamide gels: a modified procedure with enhanced uniform sensitivity. Analytical Biochemistry 117, 307-310.

Nossal, G. J. V. \& ADA, G. L. (1971). Antigens and the afferent limb of the immune response. In Antigens, Lymphoid Cells and the Immune Response, pp. 13-16.
Edited by F. J. Dixon \& M. G. Kunkel. New York \& London: Academic Press.

PATERson, J. S. (1940). The antigenic structure of organisms of the genus Listerella. Journal of Pathology and Bacteriology 51, 427-436.

READING, C. L. (1982). Theory and method of immunization in culture and monoclonal antibody production. Journal of Immunological Methods 53, 261-291.

Richardson, K. \& PARKer, C. D. (1985). Identification and occurrence of Vibrio cholerae flagellar core proteins in isolated outer membrane. Infection and Immunity 47, 674-679.

Rose, A. H. (1976). In An Introduction to Microbial Physiology, 3rd edn, pp. 16-18. London: Butterworth.

SchmitT, R., RASKa, I. \& MAYER, F. (1974). Plain and complex flagella of Pseudomonas rhodos: analysis of the fine structure and composition. Journal of Bacteriology 117, 844-857.

Seeliger, H. P. R. \& HohNe, K. (1979). Serotyping of Listeria monocytogenes and related species. Methods in Microbiology 13, 31-49.

Whiteside, T. M. \& Rhodes-Roberts, M. E. (1985). Biochemical and serological properties of purified flagella and flagellins of some Pseudomonas spp. Journal of General Microbiology 131, 873-883.

Wilson, G. S. \& Miles, A. A. (1964). Erysipelothrix and Listeria. In Topley and Wilson's Principles of Bacteriology and Immunity, 5th edn, pp. 523-535. Edited by G. S. Wilson \& A. A. Miles. London: Arnold. 